\title{
UNDERSTANDING WORKER PARTICIPATION AND \\ ORGANIZATIONAL \\ PERFORMANCE AT THE FIRM \\ LEVEL: IN SEARCH FOR AN INTEGRATED MODEL
}

\author{
Jan Kees Looise, Nicole Torka and Jan \\ Ekke Wigboldus
}

\section{ABSTRACT}

Last decades scholars in the field of human resource management (HRM) have intensely examined the contribution of HRM to organizational performance. Despite their efforts, at least one major research shortcoming can be identified. In general, they have devoted far too little attention to an aspect of HRM potentially beneficial for organizational performance: worker participation, and especially its indirect or representative forms. In contrast, for academics embedded in the industrial relations tradition, worker participation is a prominent theme, even though less emphasized in its relationship with company objectives. One might defend traditional scholars' reservations by arguing that participations main goal concerns workplace democratization and not

\footnotetext{
Advances in Industrial and Labor Relations, Volume 18, 87-113

Copyright $(C) 2011$ by Emerald Group Publishing Limited

All rights of reproduction in any form reserved

ISSN: 0742-6186/doi:10.1108/S0742-6186(2011)0000018006
} 
organizational prosperity. However, several writers state that industrial democracy involving worker participation can channel conflicts of interest between employees and employers and stimulate desired employee attitudes and behavior, consequently enhancing organizational performance (e.g., Gollan, 2006; Ramsay, 1991; Taras \& Kaufman, 1999). And, indeed, several studies have shown positive effects of both direct participation (e.g., European Foundation for the Improvement of Living and Working Conditions, 1997) and indirect participation (e.g., Addison et al., 2000, 2003; Frick \& Möller, 2003) on organizational performance.

Nevertheless, to date, the absence of an integrated model explaining the connection between worker participation and organizational performance leads to the following question that still is in need of an answer: how do direct and indirect forms of participation - separate as well as in combination - affect organizational performance? This chapter aims to contribute to the filling of the aforementioned knowledge gaps. In so doing, we focus on direct and indirect, nonunion participation on the firm level, using a Western European and especially Dutch frame of reference.

Keywords: direct participation; indirect participation; firm-level; performance; the Netherlands

\section{INTRODUCTION}

Industrial democracy is still a central theme in industrial relations (IR) debate and research. Industrial democracy refers to worker participation in both its direct and indirect or representative forms. Direct participation refers to employees' immediate communication, interaction, and co-decision making with management; indirect participation to one or more employees who act in a representative function for other employees in dealings with management. This happens in a vast variety of organizational forms including committees, councils, and unions (Kaufman \& Levine, 2000; Taras \& Kaufman, 2006).

The global economic downturn in the mid-1980s pushed adherents to the emerging human resource management (HRM) rhetoric to advocate onesided employer demands, undermining IR's position in teaching and research (themes) (Clarke et al., 2009). One of the most influential HRM models (e.g., Beer, Spector, Lawrence, Quinn Mills, \& Walton, 1984) advocated worker 
participation as one of the so-called "high performance management practices" that contribute to organizational effectiveness, and later research supported this assumption (e.g., Addison et al., 2000, 2003; Frick \& Möller, 2003). However, compared to other practices such as job design, pay, and development opportunities, participation - particularly indirect forms - and its effects have received relatively little interest in HRM studies. Many IR scholars also remained silent on the relationship between worker participation and organizational performance. This is not surprising given IR's traditional view that worker participation epitomizes industrial democracy.

Yet, an increasing number of IR scholars focused attention on the fact that worker participation, and mainly nonunion representation on the firm level, also has a fundamental economic value. These researchers emphasize that from a managerial point of view employee involvement can be seen as a business tool: worker participation as a means to reduce transaction costs associated with the employee-organization relations and, consequently, improving productivity (e.g., Colling, 2003; Frenkel, Korczynski, Donaghue, \& Shire, 1995; Freeman \& Lazaer, 1995; Gollan, 2006, 2010; Kaufman \& Taras, 2000; Kaufman \& Levine, 2000; Ramsay, 1991; Rogers \& Streeck, 1995; Taras \& Kaufman, 1999). Moreover, it can be argued sustainable successful worker participation on the firm level has to meet employers and employees interests: in this view enhanced organizational productivity and performance are aligned with an improvement of the "social good" for workers in terms of higher wages, improved working conditions, and increased job security. After all, only companies with sustained productivity and profitability are able to ensure further enhancement of workers' conditions.

Against this background, investigating the effects of worker participation for organizational performance is legitimate. This chapter addresses this issue by focusing on direct and indirect nonunion forms of worker participation on the firm level using a Western European and especially Dutch frame of reference that we know best. More specifically, the goal here is to explore possible solutions to the following puzzle: how do direct and indirect forms of participation - separate as well as in combination - affect organizational performance?

We decided to leave union involvement out of our consideration because in most Western European countries (like the Netherlands, Germany, Austria, Belgium, France, and Spain) union interference is restricted to collective, sector-level bargaining with a strong focus on remuneration packages and decision making in regard to individual organizations lies outside the unions mandate. Furthermore, Gollan (2010, p. 212) states that in Anglo countries the interest in nonunion firm-level participation is increasing because union density is in decline, and legislative changes more and more ban closed shop or 
compulsory union arrangements. For example, in the UK nonunion joint consultation between management and worker representatives seems to be growing (Hall, 2009) partly under influence of the recent European Directive on information and consultation of employees. In contrast, in the Netherlands (and other European countries) indirect nonunion worker participation is a rather old phenomenon. We can thus by concentrating on countries with a long tradition offer arguments for those who want to promote these forms of participation in countries and firms with a different history.

At the end of this chapter we present an integrative model that can guide future research on the participation-performance link and policymaking in this field. We will explore two streams of research which have shaped this model. The first concerns the connection between direct participation and employee outcomes like commitment, and consequently organizational performance. After presenting a brief overview, we proceed to concentrate on the indirect participation-organizational performance connection, with a strong focus on the role of Dutch works councils. By combining insights from the direct and indirect participation-performance links we are able to present our integrated model in the last paragraph.

\section{DIRECT PARTICIPATION AND ORGANIZATIONAL PERFORMANCE}

Direct participation can potentially touch all workers directly in relation to their work tasks, work organization, and working conditions. Such participation is strongly contingent on a voluntary management decision and can be seen as an HRM-practice (see Introduction). Despite the vast amount of research on the performance effects of HRM-practices, very little work has been done to illuminate the contribution of direct participation to organizational performance. The EPOC Group's research (European Foundation for the Improvement of Living and Working Conditions, 1997) showed it was valuable to investigate this relationship.

The EPOC Research Group studied direct participation in 10 Western European countries. ${ }^{1}$ Close to 6,000 general managers participated in this survey about the coverage, scope, and intensity of different forms of direct participation (total response rate: 17.8\%). They found evidence of direct participation in $82 \%$ of the workplaces in Western European countries, with group consultation in permanent groups as the leading form $(43 \%$ of the workplaces: $29 \%$ permanent and $14 \%$ temporary), followed by individual 
consultation (33\%), group delegation (13\%), and individual delegation $(11 \%)$. The Netherlands and Sweden had the highest scores in workplaces with direct forms of participation: $90 \%$ and $89 \%$ of the workplaces (see also Gill \& Krieger, 1999). This means that in almost all workplaces in these countries forms of direct participation exist. Positive effects of direct participation were found for three categories of performance outcomes, namely:

1. economic performance (cost reduction, reduction of throughput time, improvement of quality of product or service, increase in output);

2. indirect labor costs (decreases in sickness, absenteeism); and

3. direct labor costs (reduction in number of employees, managers).

Table 1 gives an overview of the performance effects of different forms of direct participation as perceived by the respondents as reported in the EPOC survey. In the table only three of the six investigated forms of direct participation are shown, namely, individual consultation ("face-to-face"), group consultation (permanent groups), and group delegation. Not included are individual consultation ("arms length"), group consultation (temporary groups), and individual delegation.

Table 1. The Effects of Different Forms of Direct Participation (EPOC, 1997).

\begin{tabular}{lccc}
\hline Effects & $\begin{array}{c}\text { Individual } \\
\text { Consultation (\%) }\end{array}$ & $\begin{array}{c}\text { Group } \\
\text { Consultation (\%) }\end{array}$ & $\begin{array}{c}\text { Group } \\
\text { Delegation (\%) }\end{array}$ \\
\hline $\begin{array}{l}\text { Economic performance } \\
\text { Reduction of costs }\end{array}$ & 61 & 61 & 56 \\
Reduction of throughput time & 64 & 62 & 66 \\
Improvement in quality & 92 & 94 & 94 \\
Increase in total output & 52 & 53 & 58 \\
Indirect labor costs & & & 32 \\
Decrease in sickness & 39 & 37 & 37 \\
Decrease in absenteeism & 42 & 39 & 30 \\
Direct labor costs & & & 31 \\
Reduction of number of employees & 27 & 26 & \\
Reduction in number of managers & 26 & 22 & \\
\hline
\end{tabular}


The results show direct participation has the strongest effect on economic indicators, especially quality improvement, but also on reduction of throughput time and cost and increase of the total output. The effects on indirect (i.e., decrease in sickness, decrease in absenteeism) and direct labor costs (i.e., reduction in number of employees, reduction in number of managers) seem to be weaker, but are still important.

When we take into account different forms of direct participation, the EPOC research shows that effect differences between the diverse forms of direct participation are rather small. This is also the case with reference to the forms that are missing in the table. Only group delegation seems a little more effective when it comes to direct labor costs. Another interesting finding is that temporary group delegation can be as effective as more permanent forms. It thus seems reasonable to conclude that it is more the opportunity of direct participation as such less the form of that opportunity that is decisive for organizational performance.

Although the EPOC study seems to suggest an immediate relationship between direct participation and organizational performance, based on HRM rhetoric and research, it is wise to acknowledge that intervening factors cause this connection. Numerous HRM scholars present models aiming to illustrate the HRM and performance relationship (e.g., Beer et al., 1984; Fombrun, Tichy, \& Devanna, 1984; Guest, 1997; Paauwe, 2004; Paauwe \& Richardson, 1997) and they all agree there is a relationship between the organizations' strategy, the choice for a certain HRM approach (or system), and specific outcomes or effects. For example, when choosing for quality as a strategy to foster competitive advantage, this target has to be aligned within the various HR-practices (e.g., Baird \& Meshoulam, 1988). Concerning the effects, a distinction has been made between employee and organizational outcomes. Employee outcomes refer to the effects of HRM on employee attitudes (e.g., satisfaction, commitment) and consequent behavior (e.g., absenteeism, turnover, organizational citizenship behavior $[\mathrm{OCB}])$, and these are expected to influence organization outcomes. Thus, employee attitudes and behavior are the missing link in the direct participation and organizational performance relationship (see also Cox, Zagelmeyer, \& Marchington, 2006; Purcell \& Georgiadis, 2006)

Organizational performance refers to both objective (e.g., profit, return on investment; productivity, growth) and subjective performance outcomes (e.g., quality of products and services, client satisfaction, innovativeness). Several researchers (e.g., Paauwe, 2004; Addison \& Teixeira, 2006; Forth \& $\mathrm{McNabb}$, 2008) emphasize the current common research approach to organizational performance in its sole focus on financial performance is too 
narrow. They urge an alternative use of a multidimensional performance perspective that includes further objective (e.g., employment growth) and subjective performance measures (e.g., employee well-being, societal wellbeing). We fully agree about expanding the parameters in studying organizational performance, but here limit our discussion to the more economic effects of (direct) participation.

Building on the general notions we have raised about the connection between HRM and performance, we can assume the following relationships between direct participation and organizational performance (see Fig. 1).

As Fig. 1 shows, direct participation appears to have an impact on organizational performance in three rather basic ways.

First, employees with direct participation opportunities can influence organizations' performance directly: they can offer suggestions leading to more efficient processes or better product quality. In doing so, employees can contribute to higher labor productivity and process innovation (e.g., De Leede, 1997).

Second, like other HR policies and practices, direct participation influences employee attitudes which in turn support employee behavior that is beneficial for organizational performance (e.g., reduced turnover and absenteeism, improved productivity and product quality; see also Doucouliagos, 1995; Dundon, Wilkinson, Marchington, \& Ackers, 2004). Recent findings support the assumed relationships: Torka, Schyns, and Looise (2010) found direct participation is significantly connected to affective organizational commitment, and Meyer et al.'s (2002) metaanalysis shows that this form of commitment strongly influences employee

\begin{tabular}{|l|}
\hline \multicolumn{1}{|c|}{$\begin{array}{c}\text { Organizational } \\
\text { strategy }\end{array}$} \\
cost (cost efficiency) \\
focus (quality) \\
differentiation \\
(innovation) \\
\end{tabular}

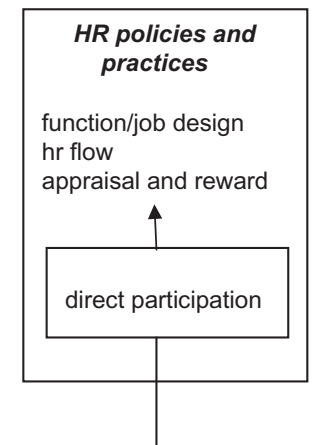

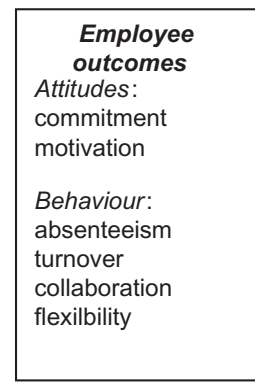

Organisation outcomes

growth labour productivity product quality product /process innovation

Fig. 1. The Relationship between Direct Participation and Organizational Performance. 
health and well-being, turnover, absenteeism as well as task- and extra-role performance (i.e., OCB). Thus, direct participation can impact organizational performance indirectly through the just mentioned employee outcomes.

Third, the model shows that direct participation has a rather prominent position as part of the HR policies and practices. In other words, managers should offer employees opportunities to (co-)decide on those HR issues that clearly affect them. Older research by Beer et al. (1984) supports this idea with two arguments: (1) "If", they claim, "employees are major stakeholders in the enterprise, then it is critical that managers design and administer various mechanisms for employee influence" and further (2) "employee influence in its broadest sense is a central perspective in the formulation of all human resource management policies." This last proposition about the critical role of both direct and indirect participation has been ignored by many scholars and practitioners. Just a sparse handful of investigators have recognized the point and gone so far as to claim direct participation should even have a special status within research on performance: direct participation presumes listening to employee needs and only when meeting their needs will desired outcomes be gained (e.g., Bryson, 2004; Bryson, Charlwood, \& Forth, 2006; Gollan, 2003; Torka, Van Riemsdijk, \& Looise, 2007). Given our review of unmistakable patterns of blind sight in the accumulated evidence, when compared to other HRM-practices, there can be little doubt that participation deserves at least equal attention in organizational performance research and practice.

Finally, Cox et al. (2006) state that more emphasis needs to be placed on the perception of direct participation. Therefore, it can be argued that getting insight into the absence or presence of participation opportunities (see, for example, Forde, Slater, \& Spencer, 2006) is less important than the quality of the given opportunities as perceived by employees. Employees' satisfaction and justice perceptions can be seen as indicators of the employee-organization relationship (EOR) quality (e.g., Coyle-Shapiro, Shore, Taylor, \& Tetrick, 2004; Kuvaas, 2008). We know from prior research that satisfaction with HR-practices is a good predictor of affective organizational commitment (e.g., Kinnie, Hutchinson, Purcell, Rayton, \& Swart, 2005; Meyer, Stanley, Herscovitch, \& Topolnytsky, 2002). Several studies show that justice perceptions are quite directly correlated with job satisfaction and organizational commitment (e.g., Colquitt, Conlon, Wesson, Porter, \& Ng, 2001; see also Colquitt, 2001 for different dimensions of justice and measurements). Moreover, managerial strategies lacking a 
perception of fairness seem to undermine productivity (Kick, Fraser, \& Davis, 2006). Therefore, we can legitimately assume employees' satisfaction with and perceived fairness concerning participation can shed significant light on the quality of participation. Finally, concerning quality, research found that participation is often seriously in need of improvement. The role of managers, the quality of participation policies and practices, and job and workforce characteristics are still insufficiently taken into account or ever even considered (e.g., Bryson et al., 2006; Cunningham \& Hyman, 1999; Torka, Van Woerkom, \& Looise, 2008).

\section{INDIRECT PARTICIPATION AND ORGANIZATIONAL PERFORMANCE}

There are, as stated earlier, good reasons to focus on indirect nonunion participation, also known as an integrative form of bargaining, like works councils and joint consultation committees, and not on union involvement (i.e., distributive forms of bargaining). In many Western European countries (the Netherlands, Germany, Austria, Belgium, France, Spain) both types of bargaining take place in different institutions, while in others (the Scandinavian countries and the United Kingdom) both forms of bargaining are executed, but in a separate mode by union representatives at the company level. According to the EPOC Research Group, forms of joint consultation exist in about half of the organizations in the ten Western European countries that participated in the research, with higher levels for Germany and the Netherlands and lower levels for the United Kingdom and Portugal (see also Gill \& Krieger, 1999). Co-determination via worker representatives in supervisory boards and worker directors can be found in Germany and the Netherlands.

In the Netherlands, only a few large companies bargain directly with unions. In large measure the unions' mandate is restricted to negotiations on the sector-level, the foremost concern being pay and benefits specified in collective agreements. The works council is the most important institution for representative participation on the firm level, and mandatory for all firms with 50 and more employees. The Dutch Law on works councils (Wet op de ondernemingsraden, WOR) states that works councils have to be installed "in the interest of the good functioning of the company in all its goals" (article 2). According to the WOR, Dutch works councils have different rights. 
First, the right to give advice about a number of economic and organizational issues, including the transfer of control over the company, lasting cooperation with other companies, the closing down of the company or parts of it, major organizational changes, major investments and loans, and - more recently the introduction of new technology.

Second, the right to veto employer proposals regarding changes in social and personnel policies, including working hours, holidays, remuneration, job evaluation schemes, working conditions, recruitment, promotion, and training. These rights are only in effect when such arrangements are not determined by a collective labor agreement.

Third, the right to appeal - in various courts - when the aforementioned rights of veto or advice are not respected by the managing director.

Fourth, the right to initiate proposals with respect to all matters related to the company, to which the employer is obliged to respond.

Finally, the right to assemble at least six times a year during work time (excluding the presence of the managing director), to follow courses outside the company (five days a year), and to consult external experts.

The rights of Dutch works councils are comparable to those in other European countries such as Germany, Austria, and Belgium.

The growing interest in involving representative firm-level participation (e.g., unions, partnerships, work councils, and other forms of joint consultation) in performance research has led to research focused on its consequences for companies. These investigations seem to be inspired by an economical-political or managerial point of view: in Western Europe, the popular discussion about the relative competitive position of European economies.

In Germany, the system of firm-level representative, nonunion participation has been long debated, questioning if the two institutions within the firm (the "betriebliche Mitbestimmung" in works councils on company issues and the "Aufsichtsrat" or supervisory board on concern issues) hamper or stimulate German competitiveness ("Standort Deutschland"). In 2006 the so-called Commission Biedenkopf concluded revision of the system was unwarranted inasmuch as research failed to detect or establish any relationship with poor company performance. In point of fact, the opposite seemed to be the case: extensive research indicated the German mandatory works councils may well improve firm performance and certain kinds of productivity (Addison et al., 2000, 2003; Frick \& Möller, 2003).

Furthermore, research in other countries shows a positive relationship between (the presence of) representative participation in firms and performance. Concerning unions on the firm level, research by Addison (2005), Rose and 
Woolley (1992), and Sengupta (2008) highlights the importance of unions for high-performance work systems and firm performance. Concerning works councils, Kleiner and Lee's (1997) research among large South Korean firms shows effective works councils can be associated with higher levels of employee satisfaction and productivity.

The debate on the performance effects of works councils has not achieved as high a level in the Netherlands as in Germany, due in part to the unavailability of empirical data on this issue. However, recent initiatives have been undertaken to address this topic in new research (Karel, Heijink, Van den Tillaart, Boekhorst, \& Van Rijsingen, 2010) and a reassessment of earlier research (Van den Berg, Grift, \& Van Witteloostuin, 2009). This research when combined with the now growing interest in economic effects of other legal and institutional arrangements (like the legal arrangements regarding dismissals and extension of collective agreements, the position and role of the unions) should fuel the debate on the economic effects of works councils in the Netherlands.

Up to now scholars have not been generally very explicit in defining the way(s) representative forms of participation like work councils can influence performance. However, Dutch research on works councils can be helpful in developing an understanding about if and how representative participation can contribute to organizational performance. Based on Van het Kaar and Looise's (1999) study on the position and functioning of Dutch works councils, three "channels" - one direct and two indirect - can be distinguished regarding the influence of works councils on company performance.

The researchers sent questionnaires to both the managing directors and works councils of a representative sample $(N=3,500)$ of all Dutch organizations with a works council (about 15,000). Four hundred and seventy five managing directors (response rate: 14\%) and 450 works council representatives (response rate: 12\%) participated in the study. Although the response rate of this study was rather low, it is in line with that of other large-scale empirical studies (for example, the EPOC research). Moreover, more recent Dutch research (Karel, et al., 2010) seems to corroborate the results. Table 1 shows the answers of both managing directors and works council members to questions about the perceived effects of works councils on organizational performance. These questions were not deliberately developed to understand the contribution of the works council to organizational performance (i.e., developed to measure some effects of works councils), but offer a welcome opportunity to understand the channels by which representative forms of participation 
can influence organizational performance (for more information, see also Wigboldus, Looise, \& Nijhof, 2008).

Table 2 shows both managing directors and works council members acknowledge performance effects of works councils. However, indirect effects seem to receive stronger recognition than direct effects, particularly in the case of managing directors. The fact both parties perceive more indirect than direct effects of works councils on organization performance is in itself not surprising inasmuch as influencing organizational performance is a major responsibility of top management and not Dutch works councils. Against this background, it is likewise unexceptional that management finds it harder to "admit" the contribution of the works council in this respect. However, the table also shows that despite managers (average) perception, even they still perceive a direct contribution of the works council to performance aspects like efficiency, profitability, and innovation.

Table 2 also shows that both indirect channels receive substantial support from managing directors and works council members. Regarding the first indirect channel, managing directors acknowledge especially the effects of works councils on employee attitudes in terms of acceptance of necessary decisions with employees, while works council members stress the improved

Table 2. Works Council Effects Based on Perceptions of Managing Directors and Works Council Members (Based on Van het Kaar \& Looise, 1999).

\begin{tabular}{lcc}
\hline Effects & $\begin{array}{c}\text { Management } \\
(\%)\end{array}$ & $\begin{array}{c}\text { Works Council Members } \\
(\%)\end{array}$ \\
\hline Direct channel & 9 & 26 \\
Enhancing efficiency & 4 & 10 \\
Enhancing profitability & 12 & 24 \\
Enhancing innovation & & \\
Indirect channel 1 & 64 & 43 \\
Improved acceptance among employees & 55 & 78 \\
Improved representation of employees' interests & 28 & 27 \\
Reduction of power differences & & 52 \\
Indirect channel 2 & 38 & 67 \\
Improvement of decision making quality & 65 & 11 \\
More careful decision making & 3 & \\
Faster decision making & & \\
\hline
\end{tabular}

Note: The values are the percentages of managing directors and works council members that have answered the questions. 
representation of employee interest in decision making. Since we can assume that both effects are interrelated - a good representation of employee interests in decision making will enhance the acceptance of the decision by the employees - the underpinning of this channel seems to be quite convincing. Also, the reduction of power differences - while less strongly supported - appears to follow from these circumstances. Finally, the second indirect channel receives ample support: It was beyond doubt that the effect of works councils on careful decision making is recognized by a large majority of both groups of respondents.

Before presenting a deeper exploration of the direct and indirect effects of representative participation on organizational performance (see also Wigboldus et al., 2008), we first present a simple explanatory model that aims to illustrate this interaction and these relationships.

The direct channel contributes to organizational performance through new information and/or new solutions. Due to their legal rights and/or their contacts with top-management, representative bodies can directly influence organizational performance, either by communicating their ideas in their meetings with top management, or advising and/or negotiating on plans and policies. By passing on new information, representative participation adds to the decision making process. This information can potentially improve management decisions and thereby adds to better performance. The specific position of works councils or committees as elected representation of all workers enables the council to acquire information that otherwise would not come to the attention of senior management without delay and distortion.

This so-called asymmetry approach is supported by Freeman and Lazaer (1995) who argue works councils' (and other committees) economic effects can depend on conveying unknown information from the work floor to management (see also Lahovary, 2000). Because of the information asymmetry between management and worker representatives, their interactions can produce new points of view and new solutions for advantageous management problem-solving. Addison (2005) found this approach sound in his study of channeling employee's preferences to be an important works council function. Although this does not produce new information to management, it helps management to deal with the different employee preferences such as work hours or benefits. Dilger (2002) has shown with his voice approach that the asymmetry effect goes beyond organization and work procedure improvement ideas. Representative bodies also may express complaints and problems that are frustrating circumspect employees, helping reduce unnecessary employee turnover and so-called mental resignation. As concluded above, the direct effect of representative participation on 
organizational performance seems to be rather limited when compared to that of indirect effects. To be sure, this does not mean it should be neglected: representative participation is able to contribute directly to organizational outcomes.

The first indirect channel contributes to organizational performance through an enhanced positive organizational climate. Organizational climate is the overall meaning derived from the aggregation of individual perceptions of a work environment (James et al., 2008, p. 15), and research shows that a positive climate affects employee and organizational outcomes in a favorable way. Climate is a critical mediating construct for exploring the relationship between HRM and performance. In a strong positive climate organizational members display significant congruence concerning organizational values, and routinely act according to these values by contributing to organizational performance through, for example, accomplishing cost effectiveness, quality, and innovativeness. (Bowen \& Ostroff, 2004; Ostroff, Shin, \& Kinicki, 2005).

Heretofore the possible positive impact of representative participation on the firm's climate has been largely neglected. However, research generally shows that participative organizational climates are perceived as more effective in terms of trust than authoritarian climates (Farris, Senner, \& Butterfield, 1973), and trust influences labor-management relations (Taylor, 1989), enhanced readiness to change (Lawler, 1992), and negotiation (Bazerman, 1994). Regarding the latter, the assumption of a reversed effect of trust seems quite appropriate: trust - an important condition and consequence of a strong climate - may influence the quality of both direct and indirect participation.

The activities of representative bodies can contribute to an organizational climate with fewer power differences, less inequality, and more trust in the organization. After all, at least in the Netherlands, works councils represent all employees and their rights; they are restricted to general employee goods, and do not extend to individual employee interests. Therefore, representative participation occurs by definition on an aggregated level: next to organizational interests, representatives embody the shared interests of (groups of) employees. As such, representative bodies operate on a climate level, and climate stimulates employee commitment and consequently performance (see also paragraph on direct participation and organizational performance and DeCotiis \& Summers, 1987; Van den Hooff \& De Ridder, 2004). Besides that, a positive organizational climate (co-)created by representative participation might have a direct positive influence on organizational performance through improved communication. Lahovary 
(2000, p. 6) supports this idea and concludes works councils intensify the communication flow between management and employees and communication, itself is critical for organizational performance (Snyder \& Morris, 1984). Given the evidence of this cascading role of a strong organizational climate, representative participation can and should be viewed and understood as an explicit attempt to integrate mutual benefits of managers' and employeesorganizational and employee well-being. What results is enhanced organizational performance.

The second indirect channel contributes to organizational performance through the organization system, and management's attitudes and behavior. In many of the (larger) Dutch organizations, the works council has developed into a player in the corporate governance structure that cannot be ignored (Van het Kaar \& Looise, 1999). Its relatively clear view of what management does and fails to do, and its communication line with the supervisory board, are crucial. They have made it possible to get dysfunctioning CEOs dismissed. Representative bodies' interventions may correct and prevent opportunistic management behavior and through this contribute to better organizational performance.

This assumption is amply supported by empirical evidence. Falkum (2003) points to the fact that performance is not only positively affected by management supporting employee participation, but also by employees resistance: for example, when employees or their representatives are opposed to bad management strategies and decisions. Van den Berg (2004) is even more specific, arguing indirect participation can restrict or even prevent management from placing their own pecuniary interests above company interests. This is possible by using information and consultation rights, as well as through interaction with the supervisory board. Van den Berg considers this mechanism an extension - albeit an unorthodox one - of the principalagent approach; although it is not meant to foster shareholder interests, it aims to put the general interest of the company above management's tendency to act opportunistically. A similar line of thinking is found in Addison (2005) who quotes Jirjahn's (2003) study. He found that works councils can contribute to company performance by curtailing rent seeking management behavior, especially when they discuss profit sharing schemes for executives. A manager working at the large German company Bayer very briefly expressed the opportunism preventing functioning of the works council: "The works council requires of us that we manage well." (in Wever, 1994, p. 475).

Finally, with regards to indirect participation, it is useful to stress that the quality of participation is decisive. The quality essentially determines the real power these institutes can have on performance, and this power may 
potentially exceed even minimum rights given by (country-specific) regulations. Representative participation quality depends on both the managers' attitudes toward such institutions, as well as the expertise and skills of representative participation agents. Moreover, it can be argued that the quality of indirect participation increases when management and worker representatives share interests. This interest alignment approach is supported by Vroom (1964), who assumes rational workers' behavior and claims a workers' effort is determined by his dual expectancy of the opportunities that this effort will lead to a certain performance and by the degree to which this performance will help to reach a certain desired outcome. Applying this idea to our subject means that representative bodies will only put effort in contributing to better profits if (a) it is likely to really have an effect on these profits, and (b) this contribution will lead to a desired outcome. Grimsrud, Kvinge, and Gunnes (2003, p. 8) support this overall line of reasoning: “( ...) to be successful, increased involvement by employees in decision making must be linked to a gain-sharing mechanism, which offers the opportunity for workers to gain financially from taking on the extra responsibility."

Freeman and Lazaer (1995) suggest works councils will only have positive economic effects in those situations where there is power equilibrium between management and works council. When works councils have too much power they will claim more of the total firm profits for the employees than they have contributed, but when they have insufficient power they will not be motivated to contribute to better firm results. Pérotin and Robinson (2002) in their study of performance effects of financial participation by employees underline that organizational performance depends not only on the working efforts of employees, but also on management decisions and external factors. They conclude that employee influence on management decisions is necessary to prevent that these decisions from harming share value and profit levels, factors that could undermine employees' efforts to earn a fair living.

\section{THE INTERRELATEDNESS OF DIRECT AND INDIRECT PARTICIPATION AND ORGANIZATIONAL PERFORMANCE}

Both direct and indirect participation can be offered by management on a voluntary basis, but it can also be mandatory for the organization - forced by laws, collective agreement(s), or union power position. Overall, direct 
forms of participation seem to be more based on voluntary management decisions, and indirect forms of participation on (legal) regulations. In the Netherlands, laws on direct participation have not emerged while there is extensive legislation law on works councils. However, it is interesting to note that there are other Dutch laws, like the one on working conditions (Arbo Law) that refer to direct participation of all employees of an organization concerning this type of issues. Moreover, the Law on works councils is patently proscriptive, instructing these organizations to stimulate direct participation in their work. Overall, works councils in the Netherlands are not very active on this topic: only half of the works councils pay attention to direct participation (Van het Kaar \& Looise, 1999). This is probably due to the fact that direct participation is already commonplace in the Netherlands and works councils give priority to other, even more demanding tasks. It may also be a result of the fact that works councils see direct forms of participation as a competitor and as a by-pass for management. There is some empirical evidence of the use of direct participation as a "unionavoidance strategy" by management (e.g., Kochan, Katz, \& McKersie, 1986). However, based on the EPOC research of Fröhlich and Pekruhl (1996), it is permissible to conclude that "our data suggest that in countries with a system of works councils or elected representatives at the establishment level, employee representatives are generally not by-passed by management" (p. 138).

Surprisingly, the relationships between direct and indirect participation and their "combined effect" on organizational performance have been rarely studied. After all, several authors explicitly assume interrelatedness between both forms of participation. Strauss (1998) stated that institutionalized indirect participation is inevitable for successful direct participation. Kleiner and Lee's (1997) and Poutsma, Ligthart, and Veersma's (2006) empirical studies support this generalization. Kleiner and Lee found that both work councils and unions enhance direct participation in several key personnel practices, while Poutsma and colleagues' research reveals substantial effects of country-specific institutions on direct participation in European firms.

In the EPOC study some attention has been given to the "regulation" of direct participation via indirect participation, as well as to the incidence and effects of both forms of participation. A first conclusion from this study is that "the extent of employee information and consultation about the introduction of direct participation is high." In on average $44 \%$ of the workplaces in the participating ten EU countries, extensive consulting with employee representative bodies like works councils or joint consultation 
committees has been about the introduction of direct participation in the work place, and $22 \%$ report that they were extensively informed or limited consulted. Only $34 \%$ report no involvement of indirect participation in the introduction of direct participation. These findings suggest that (according to a majority) direct participation should not be seen as a purely "management instrument" aimed at weakening the role of indirect participation, but rather as an instrument or HR-practice approved by the works council or similar bodies (see also Gill \& Krieger, 1999).

Furthermore, the results also show the (potential) role of indirect participation in the introduction of HR-practices as discussed above. In the case of the Netherlands the Law on works councils governs the effect of the veto-right of works councils on social and personnel matters. However, the EPOC results do show that in other European countries representative bodies are also entitled to be informed about or to be consulted over HR-practices like the introduction of direct participation.

A third fundamental conclusion is that according to managers the extent of representative bodies involvement affects the actual (assumed) performance outcomes of direct participation. Table 3 gives an overview of the effects of direct participation in combination with no involvement (No), limited consultation (Limited), and extensive consultation (Extensive) with indirect participation. The table shows that in every case the effects of direct participation are stronger when representative bodies were consulted on the

Table 3. The Extent of Indirect Participation in the Introduction of Direct Participation and the Effects of Direct Participation (EPOC, 1997).

\begin{tabular}{lccc}
\hline Effects & No (\%) & Limited (\%) & Extensive (\%) \\
\hline Economic effects & 47 & 65 & \\
Reduction of costs & 61 & 66 & 61 \\
Reduction of throughput time & 90 & 91 & 96 \\
Improvement in quality & 13 & 47 & 63 \\
Increase in total output & & & 44 \\
Effects on indirect labor costs & 15 & 33 & 48 \\
Decrease in sickness & 16 & 37 & 34 \\
Decrease in absenteeism & & & 35 \\
Effects on direct labor costs & 28 & 31 & \\
Reduction of number of employees & 23 & 21 & \\
Reduction in number of managers & &
\end{tabular}


introduction of direct participation. This seems to be true for economic effects like cost reduction and increase of total output, and with indirect labor cost effects like decreasing sickness and absenteeism. With the exception of cost reduction and reduction of throughput time, the effect is even stronger when the consultation with employee representatives is more extensive.

With this background of specific results and our earlier presented models (anchored in an exploration of prior research and theory) about the way(s) direct and indirect participation can independently influence organizational performance, we are now able to offer an integrated model on their combined effects on organizational performance.

Fig. 3 shows the combination of Figs. 1 and 2, highlighting their mutual connections. This model illustrates that both direct and indirect participation have their own roles and functions within organizations, and that there is no foundation for the fear by either of the other taking over (part of) these roles or functions. In other words, the role and function of representative participation cannot be taken over by direct participation, or vice versa. A second critical point is the role of indirect participation with respect to HRM and direct participation. Indirect participation is not (only) an HRMpractice: indirect participation can potentially "co-design" HRM policies and practices. Representative committees anchored in legal regulations (like Dutch works councils) have a prescribed agenda to discuss and co-decide on a list of HRM topics such as benefits, job design, and employee health. In that sense, indirect participation channels influences on HRM policies and practices such as those related to direct forms of participation. However, when indirect participation lacks such protection from legal regulations and

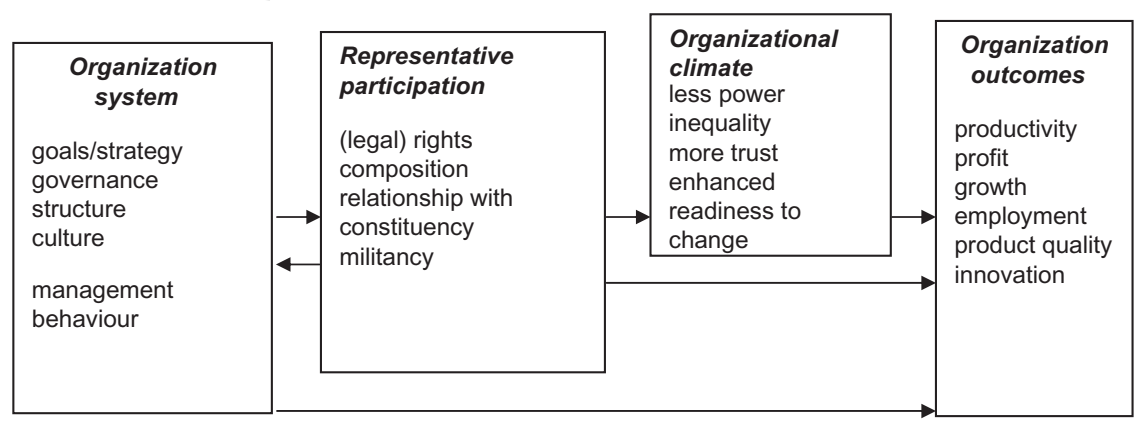

Fig. 2. The Relationship between Indirect Participation and Organizational Performance. 


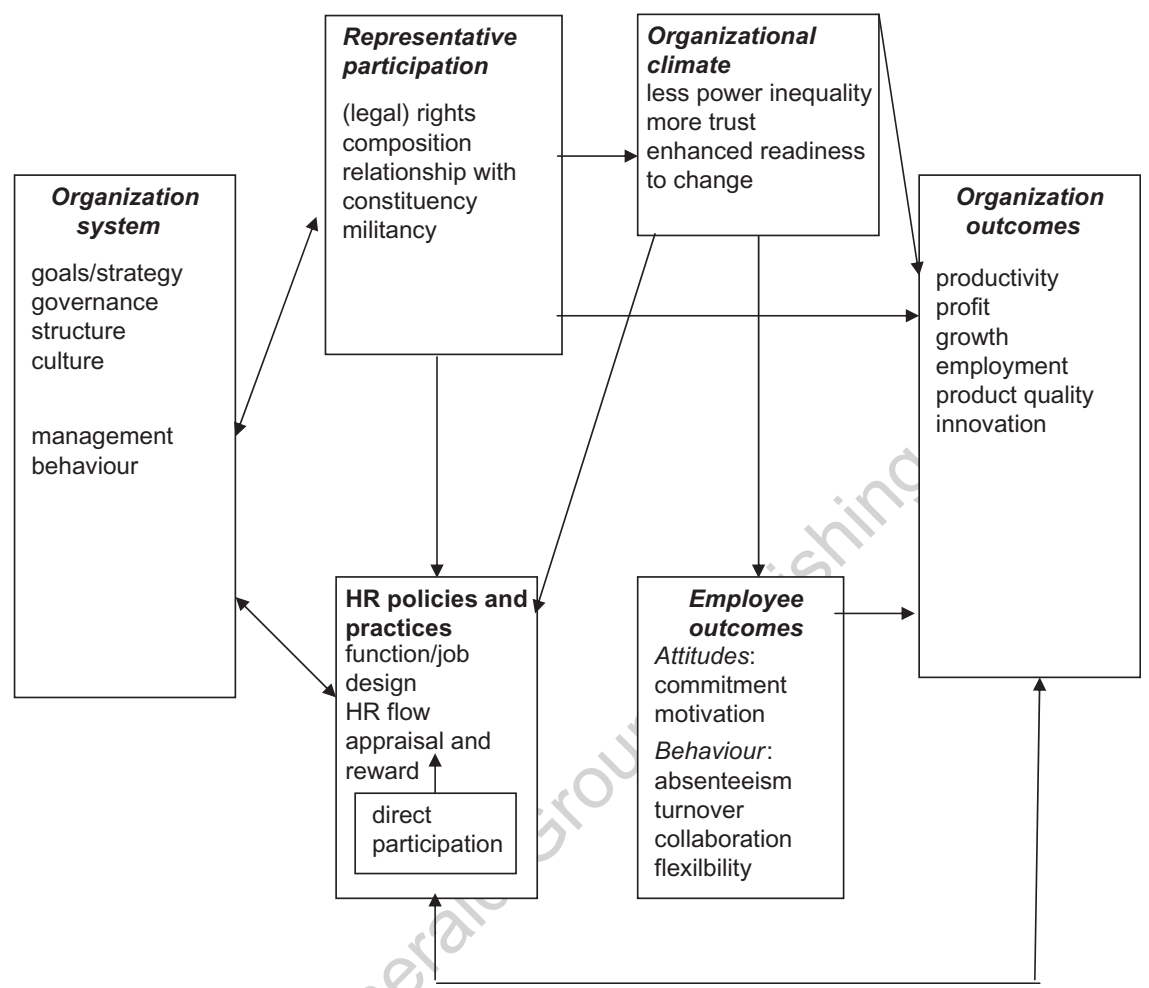

Fig. 3. An Integrated Model for HRM, Participation, and Organization Performance.

thereby legal rights, "real" influence and power concerning issues that affect employees depend even more on representatives' quality (e.g., skills, knowledge).

Members of these indirect bodies should be progressively more aware of these options, and use them to strengthen direct and indirect participation in their organizations. A third important point is the combination of social climate and employee outcomes, especially commitment. While social climate refers to collective experiences, employee consequences such as commitment and satisfaction refer to the impact of participation on individuals' perception. However, research shows that collective and individual experiences are interrelated (Carr, Schmidt, Ford, \& DeShon, 2003) and have a clear-cut positive impact upon performance (Katz, Kochan, \& Weber, 1985). 


\section{CONCLUSION AND DISCUSSION}

Our aim was to contribute to the understanding of the way(s) direct and indirect worker participation - separate and in combination - can contribute to organizational performance. After all, knowledge about this blending and especially indirect participations' potential contribution is still limited. Our integrated model adds to the development of this stream of scholarly (and perhaps also practitioner) attention and should be extended in further empirical research.

The first step of our approach concerned the relationship between direct participation and organizational performance. Grounded in prior literature and research, it can be assumed direct participation is an HR-practice, like other HRM-practices. As a consequence, direct participation similarly contributes to employee outcomes and organizational performance like those other HR-practices. However, we argued there are two basic reasons that direct participation in comparison with other HR-practices holds a special position: (1) direct participation can directly contribute to company performance (in terms of suggestions for improvement of products, processes, organizational features) and (2) direct participation can influence the development and implementation of other HR-practices. In our opinion these possible contributions of direct participation deserve more theoretical and empirical recognition. Given its extensive diffusion in (European) organizations - and in fact practitioners seem aware of the possible impact of this form of participation (EPOC, 1997) - there is an urgent need for further exploration of this part of the model.

In our second step, we portrayed the relationship between indirect forms of worker participation and organizational performance. Our focus in the main was on institutionalized forms of representative participation in Western European countries - those who practice integrative forms of bargaining like works councils and joint consultation committees. Relying on Dutch research we argued representative bodies can influence organizational performance via three channels, one direct and two indirect. The direct channel relates to representative participations direct contributions to organizational performance (e.g., suggestion for improving efficiency, profitability, and innovativeness).

The first indirect channel operates through indirect participations' potential strength to enhance an organizational climate that influences employees and organizational outcomes. The activities of representative bodies can lead to an organizational climate with less power differences and inequality, and more trust in the organization. Such an organizational 
climate will in its turn lead to better employee outcomes and consequently organizational effectiveness. Moreover, a positive organizational climate can directly influence organizational outcomes. The second indirect channel works through the organization system and management attitudes and behavior. Representative bodies' interventions may correct and prevent opportunistic management behavior and thus this contributes to better organizational performance. More comparative international research on this aspect of the model is badly needed.

In our third step, we blended together the "separate" knowledge from steps 1 and 2 into an integrated model. Additional empirical evidence leads us to claim that direct and indirect participation are closely interrelated. After all, research shows that in a majority of cases consultation of representative bodies precedes the introduction of direct participation. Thus, these forms of participation should not be seen as "competitors," but rather as "partners." Moreover, the involvement of indirect participation in the introduction of direct participation seems to add to the effects of direct participation (especially economic effects like cost reduction and increase of total output; and indirect labor cost effects like decrease of sickness and absenteeism). In our integrated model this has been explained by the positive effect of indirect participation on the introduction and implementation of direct participation, organizational climate, and employee outcomes; these stimulate the effects of direct participation on organizational outcomes. In follow-up studies we will test this model in an international context.

We recognize but have not discussed here the special role manager's expertise and skills play for successful worker participation (e.g., Bryson, 2004; Bryson et al., 2006). The significance of direct supervisors' attitudes and behaviors, as well as top managers' competence to direct these, cannot be underestimated. Concerning the ideal of fairness, compared to relevant others, there is no doubt that both participation as an "outcome" (distributive justice) and the process of participation (procedural justice) itself are vitally important. The inclusion of both of these relevant variables the role of the managers' and direct supervisor a well as justice - is still relatively rare in research focused on participation in general or the "isolated" participation-performance link. Regarding the latter, a comparable conclusion is appropriate for the role of the social climate, employee outcomes (attitudes and behavior), possible routes in the participationperformance chain, and broader operationalization of performance.

Theoretical and empirical insights support our idea that research on indirect participation deserves more sustained interest. Future research 
should aim for answers on how to improve not only organizational, but also employee and societal well-being. Our insights, largely based on the work of colleagues, can enhance the position or increase the implementation probability of representative, nonunion participation in contexts of choice where such arrangements are rather new or upcoming. On the organizational level, this knowledge can be beneficial for managers in their general design of HRM, as well as in upgrading their capability of coming to terms with representative participation. HR managers and consultants may profit from this knowledge when advising top management, and the agents of representative participation may "exploit" these ideas to improve their use of intervention strategies.

\section{NOTE}

1. These countries were (in alphabetical order) Denmark, France, Germany, Ireland, Italy, Netherlands, Portugal, Spain, Sweden, and United Kingdom.

\section{REFERENCES}

Addison, J. T. (2005). The determinants of firm performance: unions, works councils, and employee involvement/high performance work practices. Scottish Journal of Political Economy, 52, 406-450.

Addison, J. T., Siebert, S., Wagner, J., \& Wei, X. (2000). Worker participation and firm performance: Evidence from Germany and Britain. British Journal of Industrial Relations, 38, 7-48.

Addison, J. T., Schnabel, C., \& Wagner, J. (2003). The course of research into the economic consequences of German works councils. British Journal of Industrial Relations, 42, $255-282$.

Addison, J. T., \& Teixeira, P. (2006). The effect of work councils on employment change. Industrial Relations, 45, 1-25.

Baird, L., \& Meshoulam, I. (1988). Managing two fits in of strategic human resources management. Academy of Management Review, 13, 116-128.

Bazerman, M. H. (1994). Judgment in management decision making. New York: Wiley.

Beer, M., Spector, B., Lawrence, P. R., Quinn Mills, D., \& Walton, R. E. (1984). Managing human assets. New York: The Free Press.

Bowen, D. E., \& Ostroff, C. (2004). Understanding HRM-firm performance linkages: The role of the "strength" of the HRM system. Academy of Management Review, 29, 203-221.

Bryson, A. (2004). Managerial responsiveness to union and nonunion worker voice in Britain. Industrial Relations, 43, 213-241.

Bryson, A., Charlwood, A., \& Forth, J. (2006). Worker voice, managerial response and labour productivity. An empirical investigation. Industrial Relations Journal, 37, 438-455. 
Carr, J. Z., Schmidt, A. M., Ford, J. K., \& DeShon, R. P. (2003). Climate perceptions matter: A meta-analytic path analysis relating molar climate, cognitive and affective states, and individual level work outcomes. Journal of Applied Psychology, 88, 605-619.

Clarke, L., Donnelly, E., Hyman, R., Kelly, J., McKay, S., \& Moore, S. (2009). What's the point of industrial relations? A statement by the British Universities Industrial Relations Association. Available at http://docs.google.com/viewer?a $=v \& q=$ cache:ATvxi OesCp0J:bollettinoadapt.unimore.it/allegati/09_4S_13_SCIOPERO.pdf + british + universities + industrial + relations + association $\& \mathrm{hl}=\mathrm{nl} \& \mathrm{gl}=\mathrm{nl} \& \operatorname{sig}=\mathrm{AHIEtbRkALfein}$ 4NCwwaKMFxfaPeLCD9ow. Accessed on 31 January 2010.

Colling, T. (2003). Managing without unions: The sources and limitations of individualism. In: P. Edwards (Ed.), Industrial relations: Theory and practice (2nd ed., pp. 368-391). Oxford: Wiley-Blackwell.

Colquitt, J. A. (2001). On the dimensionality or organizational justice: A construct validation of a measure. Journal of Applied Psychology, 86, 386-400.

Colquitt, J. A., Conlon, D. E., Wesson, M. J., Porter, C. O., \& Ng, K. Y. (2001). Justice at the millennium: A meta-analytic review of 25 years of organizational justice research. Journal of Applied Psychology, 86, 425-445.

Cox, A., Zagelmeyer, S., \& Marchington, M. (2006). Embedding employee involvement and participation at work. Human Resource Management Journal, 16, 250-267.

Coyle-Shapiro, J. A.-M., Shore, L. M., Taylor, M. S., \& Tetrick, L. E. (Eds). (2004). The employment relationship: Examining psychological and contextual perspectives. Oxford: Oxford University Press.

Cunningham, I., \& Hyman, J. (1999). The poverty of empowerment? A critical case study. Personnel Review, 28, 192-207.

DeCotiis, T. A., \& Summers, T. P. (1987). A path analysis of a model of the antecedents and consequences of organizational commitment. Human Relations, 40, 444-470.

De Leede, J. (1997). Innoveren van onderop; over de bijdrage van taakgroepen aan product- en procesvernieuwing. Deventer: Kluwer Bedrijfsinformatie.

Dilger, A. (2002). Ökonomik betrieblicher Mitbestimmung. Die wirtschaftlichen Folgen von Betriebsräten. München and Mering: Rainer Hampp Verlag.

Doucouliagos, R. (1995). Worker participation and productivity in labor-managed and participatory capitalist firms: A meta-analysis. Industrial and Labor Relations Review, 49, $58-77$.

Dundon, T. A., Wilkinson, A., Marchington, M., \& Ackers, P. (2004). The meanings and purpose of employee voice. International Journal of Human Resource Management, 15, $1149-1170$.

European Foundation for the Improvement of Living and Working Conditions. (1997). P+ No. 13, Dublin.

Falkum, E. (2003). HRM and IR perspectives - Antagonistic or compatible? Conceptual constraints in studies of participation and performance, Paper to the IIRA 13th World Congress, Berlin, September 8-12, 2003.

Farris, G. F., Senner, E. E., \& Butterfield, D. A. (1973). Trust, culture and organizational behaviour. Industrial Relations, 12, 144-157.

Fombrun, C. J., Tichy, N. M., \& Devanna, M. A. (1984). Strategic human resource management. New York: Wiley.

Forde, C., Slater, G., \& Spencer, D. A. (2006). Fearing the worst? Threat, participation and workplace productivity. Economic and Industrial Democracy, 27, 369-398. 
Forth, J., \& McNabb, R. (2008). Workplace performance: A comparison of subjective and objective measures in the 2004 Workplace Employment Relations Survey. Industrial Relations Journal, 39, 104-123.

Freeman, R. B., \& Lazaer, E. P. (1995). An economic analysis of works councils. In: J. Rogers \& W. Streeck (Eds), Works councils: Consultation, representation, and cooperation in industrial relations (pp. 27-52). Chicago: The University of Chicago Press.

Frenkel, S., Korczynski, M., Donaghue, L., \& Shire, H. (1995). Re-constituting work: Trends towards knowledge work and info-normative control. Work, Employment and Society, 9 , 773-796.

Frick, B., \& Möller, I. (2003). Mandated works councils and firm performance: Labor productivity and personnel turnover in German establishments. Schmollers Jahrbuch. Zeitschrift für Wirtschafts- und Sozialwissenschaften, 123, 423-454.

Fröhlich, D., \& Pekruhl, U. (1996). Direct participation and organisational change, fashionable but misunderstood? An analysis of recent research in Europe, Japan and the USA, Dublin.

Gill, C., \& Krieger, H. (1999). Direct and representative participation in Europe: Recent survey evidence. International Journal of Human Resource Management, 10, 572-591.

Gollan, P. J. (2003). All talk but no voice: Employee voice at the Eurotunnel call centre. Economic and Industrial Democracy, 24, 509-541.

Gollan, P. J. (2006). Employee representation in non-union firms. London: Sage Publications.

Gollan, P. J. (2010). Employer strategies towards non-union collective voice. In: A. Wilkinson, P. J. Gollan, M. Marchington \& D. Lewin (Eds), The Oxford handbook of participation in organizations (pp. 212-236). Oxford: Oxford University Press.

Grimsrud, B., Kvinge, T., \& Gunnes, S. (2003). Productivity puzzles - Should employee participation be an issue? Paper to the IIRA 13th World Congress, Berlin, September $8-12,2003$.

Guest, D. E. (1997). Human resource management and performance: A review and research agenda. International Journal of Human Resource Management, 8, 263-276.

Hall, R. (2009). Rapporteur's report-track 1: Management, work and organizations - The challenge of contemporary transformations: Recent developments in management, work and organisations. Proceedings of the 15th World Congress of the International Industrial Relations Association IIRA 2009 'The New World of Work, Organisations and Employment', Sydney, Australia, August 27th, 2009.

James, L. R., Choi, C. C., Chia-Huei, E. K., McNeil, P. K., Minton, M. K., Wright, M. A., et al. (2008). Organizational and psychological climate: A review of theory and research. European Journal of Work and Organizational Psychology, 17, 5-32.

Jirjahn, U. (2003). Executive incentives, works councils and firm performance. Schmollers Jahrbuch, 123, 397-421.

Karel, J., Heijink, J., Van den Tillaart, H., Boekhorst, L., \& Van Rijsingen, B. (2010). Inzet en invloed van de OR. Medezeggenschapsmonitor (12) 2008. Amsterdam: Reed Business.

Katz, H. C., Kochan, T. A., \& Weber, M. R. (1985). Assessing the effects of industrial relations systems and efforts to improve the quality of working life and organizational effectiveness. Academy of Management Journal, 28, 509-526.

Kaufman, B. E., \& Levine, D. I. (2000). An economic analysis of employee representation. In: B. E. Kaufman \& D. G. Taras (Eds), Nonunion employee representation. History, contemporary practice, and policy (pp. 149-175). New York: M. E. Sharpe. 
Kaufman, B. E., \& Taras, D. G. (2000). Nonunion employee representation. History, contemporary practice, and policy. New York: M. E. Sharpe.

Kick, E. L., Fraser, J. C., \& Davis, B. L. (2006). Performance management, managerial citizenship and worker commitment: A study on the United States postal service with some global implications. Economic and Industrial Democracy, 27, 137-172.

Kinnie, N., Hutchinson, S., Purcell, J., Rayton, B., \& Swart, J. (2005). Satisfaction with HR practices and commitment to the organisation: Why one size does not fit all. Human Resource Management Journal, 15, 9-29.

Kleiner, M. M., \& Lee, Y.-M. (1997). Work councils and unionization: Lessons from South Korea. Industrial Relations, 36, 1-16.

Kochan, T. A., Katz, H. C., \& McKersie, T. (1986). The transformation of American industrial relations. New York: Basic Books.

Kuvaas, B. (2008). An exploration of how the employee-organization relationship affects the linkage between perception of developmental human resource practices and employee outcomes. Journal of Management Studies, 45, 1-25.

Lahovary, C. (2000). Employee representation, co-determination, and business performance. Literature survey on factual, empirical, and legal issues, Paper prepared for the DTI Company Law Review (ESRC Centre for Business Research).

Lawler, E. E. (1992). The ultimate advantage: Creating the high-involvement organization. San Francisco: Jossey-Bass.

Meyer, J. P., Stanley, D. J., Herscovitch, L., \& Topolnytsky, L. (2002). Affective, continuance and normative commitment to the organization: A meta-analysis of antecedents, correlates, and consequences. Journal of Vocational Behavior, 61, 20-52.

Ostroff, C., Shin, Y., \& Kinicki, A. J. (2005). Multiple perspectives of congruence: Relationships between value congruence and employee attitudes. Journal of Organizational Behavior, 26, 591-623.

Paauwe, J. (2004). HRM and performance. Achieving long term viability. Oxford: Oxford University Press.

Paauwe, J., \& Richardson, R. R. (1997). Introduction: Special issue on HRM and performance. International Journal of Human Resource Management, 8, 257-362.

Pérotin, V., \& Robinson, A. (2002). Employee participation in profit and ownership: A review of the issues and evidence. Luxembourg: European Parliament.

Poutsma, E., Ligthart, P. E. M., \& Veersma, U. (2006). The diffusion of calculative and collaborative HRM practices in European firms. Industrial Relations, 45, 513-546.

Purcell, J., \& Georgiadis, K. (2006). Why should employers bother with worker voice? In: R. Freeman, P. Boxall \& P. Haynes (Eds), What workers say: Employment voice in the Anglo-American World. Ithaca, NY: Cornell University Press.

Ramsay, H. (1991). Reinventing the wheel? A review of the development and performance of employee involvement. Human Resource Management Journal, 1, 1-22.

Rogers, J., \& Streeck, W. (1995). Work councils: Consultations, representations, and cooperation in Industrial Relations. Chicago: University of Chicago Press.

Rose, E., \& Woolley, T. (1992). Shifting sands? Trade unions and productivity at Rover cars. Industrial Relations Journal, 23, 257-267.

Sengupta, S. (2008). The impact of employee-share-ownership schemes on performance in unionised and non-unionised workplaces. Industrial Relations Journal, 39, 170-190.

Snyder, R. A., \& Morris, J. H. (1984). Organizational communication and performance. Journal of Applied Psychology, 69, 461-465. 
Strauss, G. (1998). An overview. In: F. Heller, E. Pusic, G. Strauss \& B. Wilpert (Eds), Organizational participation: Myth and reality (pp. 8-39). Oxford: Oxford University Press.

Taras, D. G., \& Kaufman, B. E. (1999). What do nonunions do? What should we do about them? MIT taskforce working paper prepared for the May 25-26 conference, 'Symposium on changing employment relations and new institutions on representation'.

Taras, D. G., \& Kaufman, B. E. (2006). Nonunion employee representation in North America: Diversity, controversy, and uncertain future. Industrial Relations Journal, 37, 513-542.

Taylor, R. G. (1989). The role of trust in labor-management relations. Organization Development Journal, 7, 85-89.

Torka, N., Schyns, B., \& Looise, J. C. (2010). Direct participation quality and organisational commitment: The role of leader-member exchange. Employee Relations, 32, 418-434.

Torka, N., Van Riemsdijk, M., \& Looise, J. C. (2007). Werkgeversbetrokkenheid. Tijdschrift voor Arbeidsvraagstukken, 23, 45-59.

Torka, N., Van Woerkom, M., \& Looise, J. C. (2008). Direct employee involvement quality (DEIQ). Creativity and Innovation Management, 17, 147-154.

Van den Berg, A. (2004). The contribution of work representation to solving the governance structure problem. Journal of Management and Governance, 8, 129-148.

Van den Berg, A., Grift, Y., \& Van Witteloostuin, A. (2009). Ökonomische Auswirkungen des Zusammenspiels von Managern und Betriebsräten. WSI-Mitteilungen, pp. 78-85.

Van den Hooff, B., \& De Ridder, J. A. (2004). Knowledge sharing in context: The influence of organizational commitment, communication climate and CMC use on knowledge sharing. Journal of Knowledge Management, 8, 117-130.

Van het Kaar, R., \& Looise, J. C. (1999). De volwassen OR. Groei en grenzen van de Nederlandse ondernemingsraad., Alphen aan den Rijn: Samson.

Vroom, V. H. (1964). Work and motivation. New York: Wiley.

Wever, K. (1994). Learning from works councils: Five unspectacular cases from Germany. Industrial Relations, 33, 467-481.

Wigboldus, J. E., Looise, J. C., \& Nijhof, A. (2008). Understanding the effects of works councils on organizational performance. A theoretical model and results from initial case studies from the Netherlands. Management Revue, 19, 307-323. 